\title{
Studi Faktor Risiko Preeklamsi terhadap Kejadian Asfiksia Neonatorum di RSUD dr. Sayidiman Magetan Tahun 2018
}

\author{
Vivian Ade Wilsye Maria Mongdong ${ }^{1}$, Rivan Virlando Suryadinata ${ }^{2 *}$, Sawitri Boengas ${ }^{2}$, \\ Siti Ariffatus Saroh ${ }^{3}$ \\ Mahasiswa Fakultas Kedokteran, Universitas Surabaya (UBAYA), Surabaya ${ }^{1}$ \\ Fakultas Kedokteran, Universitas Surabaya (UBAYA), Surabaya ${ }^{2}$ \\ RSUD dr. Sayidiman Magetan, Magetan ${ }^{3}$ \\ *e-mail: rivan.virlando.suryadinata@gmail.com
}

\begin{abstract}
Abstrak
Salah satu komplikasi kehamilan yang cukup berbahaya adalah preeklamsia. Peningkatan tekanan darah menjadi faktor utama penanda ibu hamil yang menderita preeklamsia. Berbagai komplikasi dapat meningkatkan resiko terjadinya mortalitas dan morbiditas pada ibu dan janin. Saat proses kelahiran, janin yang dikandung oleh ibu dengan preeklamsia akan lebih berisiko terkena afiksia neonatorum. Penelitian ini bertujuan untuk mengetahui risiko preeklamsi terhadap kejadian asfiksia neonatorum di RSUD dr. Sayidiman Magetan pada tahun 2018. Metode yang digunakan adalah observational dengan desain cross sectional. Pengambilan data dilakukan dengan menggunakan rekam medis pasien. Hasil penelitian menunjukkan adanya perbedaan angka kejadian afiksia neonatorum pada ibu hamil preeklamsia dengan nonpreeklamsia $(p=0,000)$. Selain itu, ibu hamil dengan preeklamsia memiliki resiko lebih tinggi melahirkan dengan asfiksia neonatorum $(\mathrm{OR}=3,071)$. Pada penelitian ini dapat disimpulkan kejadian afiksia neonatorum pada preeklamsia 3 kali lebih berisiko dibandingkan pada nonpreeklamsia di RSUD dr. Sayidiman Magetan Tahun 2018.
\end{abstract}

Kata Kunci: Faktor Risiko, Preeklamsia, Afiksia Neonatorum, RSUD dr. Sayidiman

\section{Study of Preeclampsia Risk Factors on the Incidence of Asphyxia Neonatorum at RSUD dr. Sayidiman Magetan in 2018}

\begin{abstract}
One of the complications of pregnancy which is quite dangerous is preeclampsia. Increased blood pressure is a major indicator for pregnant women from preeclampsia. Various complications lead to increased risk of mortality and morbidity in the mother and fetus. During the birth process, the fetus that is conceived by a mother with preeclampsia, have a higher risk of developing neonatal asphyxia. This study aims was to determine the risk of preeclampsia on the incidence of neonatal asphyxia in dr. Sayidiman Magetan Hospital in 2018. The method used was observational with a cross sectional design. Data were collected using patient medical records. The results showed there was a difference in the incidence of neonatal asphyxia in preeclampsia and non-preeclampsia pregnant women $(p=0.000)$. Pregnant women with preeclampsia had a higher risk of giving birth with neonatal asphyxia $(O R=3,071)$. In this study, it can be concluded that the risk of incidence of neonatal asphyxia is 3 times higher in preeclampsia than in nonpreeclampsia at dr. Sayidiman Magetan in 2018.
\end{abstract}

Keywords: Risk Factors, Preeclampsia, Asphyxia Neonatorum, RSUD dr. Sayidiman 
Studi Faktor Risiko Preeklamsi terhadap Kejadian Asfiksia Neonatorum di RSUD dr. Sayidiman... Vivian Ade Wilsye Maria Mongdong, Rivan Virlando Suryadinata, Sawitri Boengas, Siti Ariffatus Saroh

\section{PENDAHULUAN}

Preeklamsia menjadi salah satu permasalahan kesehatan di seluruh dunia yang berdampak pada kematian ibu dan bayi terutama pada negara berkembang dengan penghasilan yang rendah dan menengah (Carty et al, 2010). Di Indonesia, peningkatan proporsi preeklamsia telah meningkat sejak 3 tahun terakhir (De Giacomi et al, 2018). Preeklamsia merupakan sindroma kehamilan yang memiliki pathogenesis yang kompleks dari insufisiensi plasenta hingga stress oksidatif yang mengakibatkan kerusakan jaringan endotel (El-Sayed, 2017). Berbagai radikal bebas berperan terhadap kejadian stress oksidatif yang diakibatkan peningkatan radikal bebas yang berlebihan (Suryadinata and Wirjatmadi, 2020a). Preeklamsia ditandai dengan peningkatan tekanan darah pada usia kehamilan lebih dari 20 minggu dan lebih dari satu tanda-tanda komplikasi maternal (Tranquilli et al, 2014).

Pelayanan selama masa kehamilan, persalinan, dan nifas berperan penting bagi keberlangsungan hidup ibu dan bayi terutama ibu hamil yang memiliki riwayat preeklamsia. Salah satu komplikasi dari preeklamsia adalah afiksia neonatorum, diperkirakan angka kematian akibat asfiksia neonatorum sebesar $23 \%$ dari total kematian neonatal di dunia. Jumlah bayi baru lahir yang mengalami afiksia telah mencapai 3\% atau sekitar 3,6 juta dan 1 juta diantaranya mengalami mortalitas (WHO,2016). Pada negara maju, komplikasi preeklamsia lebih sedikit ditemukan dibandingkan pada negara berkembang (Uzan et al, 2011). Tahun 2016, Indonesia menargetkan untuk Angka Kematian Ibu sebesar 305 per 100.000 kelahiran hidup. Pada tahun 2017, AKI (Angka Kematian Ibu) Provinsi Jawa Timur mencapai 91,92 per 100.000 kelahiran hidup. Angka ini mengalami peningkatan dibandingkan tahun 2016 yang mencapai 91 per 100.000 kelahiran hidup. Berbagai penyebab kematian ibu di Provinsi Jawa Timur Tahun 2013-2017 adalah preeklamsi/eklamsi, perdarahan, infeksi, jantung, dan penyebab lainnya. Sedangkan kematian bayi yang disebabkan oleh afiksia diperkirakan sebesar 11\% (Profil Kesehatan Provinsi Jawa Timur, 2017).

Preeklamsia memperlihatkan tingkat keparahan bila terjadi peningkatan sistolik lebih dari $160 \mathrm{mmHg}$ dan atau tekanan darah diastolik $110 \mathrm{mmHg}$, atau terjadi bersamaan degan sindrom HELLP. Keparahan tersebut akan disertai dengan hemolysis, penurunan trombosit hingga kurang dari 150.000 dan peningkatan kadar transaminase di hati sebesar dua kali lipat dari nilai normal (Mayrink et al, 2018). Patofisiologi dari preeklamsia belum sepenuhnya dapat dijelaskan, namun 
terdapat dua tahap yang saling memiliki keterkaitan yaitu plasentasi abnormal dan respon inflamasi (Burton et al, 2009; Redman et al, 2015). Penyebab preeklamsi terdiri dari berbagai macam faktor yang meliputi invasi trofoblastik abnormal, faktor imunologis, aktivasi sel endotel, faktor genetik yang berdampak pada ibu, plasenta, dan janin (Cunningham, 2018). Faktor ekternal juga berpengaruh terhadap preeklamsia seperti aktivitas fisik dan nutrisi (Spracklen et al, 2016). Aktivitas fisik akan dipengaruhi dengan peningkatan usia, sedangkan nutrisi dipengaruhi oleh asupan ibu sebelum dan ketika hamil (Grum et al, 2018; Suryadinata et al, 2020b). Defisiensi Vitamin $D$ juga dapat menjadi pemicu timbulnya preeklamsia, dikarenakan vitamin $D$ memiliki sifat anti-inflamasi (Purswani et al, 2017). Pada negara tropis seperti Indonesia, permasalahan defisiensi vitamin $D$ juga banyak dijumpai dijumpai di masyarakat (Suryadinata et al, 2018). Kondisi preeklamsi pada ibu hamil akan mempengaruhi kondisi janin yang dilahirkan. Berbagai efek dapat ditimbulkan antara lain asfiksia neonatorum, intra uterine growth retardation (IUGR), prematur, ablasio plasenta, berat badan lahir rendah dan kematian janin. Kematian yang disebabkan oleh asfiksia menduduki posisi ketiga dari penyebab kematian secara global menurut WHO. Insiden asfiksia neonatorum di negara berkembang lebih tinggi daripada di negara maju (WHO, 2013).

Kejadian asfiksia yang disebabkan oleh preeklamsi terjadi karena adanya disfungsi endotel, sehingga keseimbangan antara kadar hormon vasokonstriktor (endotelin, tromboksan, angiotensin) dan vasodilator (nitritoksida, prostasiklin) menjadi terganggu. Vasokonstriksi yang meluas menyebabkan hipertensi dan pada ginjal terjadi peningkatan plasma protein melalui membran basalis glomerulus yang akan menyebabkan proteinuria (Setiyaningrum, 2017). Vasokonstriksi juga berdampak pada kurangnya suplai darah ke plasenta sehingga terjadi hipoksia janin dan akan berdampak pada ganguan pertukaran gas antara oksigen dan karbon dioksida sehingga terjadi asfiksia neonatorum (Fisher, 2015; Mayrink et al, 2018). Selain itu, kejadian asfiksia neonatorum berarti terjadi hipoksia (kekurangan oksigen) yang menimbulkan metabolisme anaerob sehingga terjadi penimbunan karbon dioksida, cairan tubuh, dan asidosis darah (Ida,2008; Redman, 2015).

Pada penelitian ini, peneliti ingin mengetahui hubungan kejadian preeklamsia dengan kejadian afiksia pada anak di RSUD dr. Sayidiman Magetan pada Tahun 2018. Hal tersebut bertujuan agar dapat memberikan gambaran dan rencana 
Studi Faktor Risiko Preeklamsi terhadap Kejadian Asfiksia Neonatorum di RSUD dr. Sayidiman... Vivian Ade Wilsye Maria Mongdong, Rivan Virlando Suryadinata, Sawitri Boengas, Siti Ariffatus Saroh

pencegahan dalam mengurangi dampak komplikasi dari ibu hamil dengan preeklamsia di wilayah sekitarnya.

\section{METODE}

Penelitian ini merupakan jenis penelitian analitik observasional dengan desain cross sectional yang bertujuan untuk mengetahui faktor risiko preeklamsi terhadap kejadian asfiksia neonatorum. Penelitian ini dilakukan di RSUD Dr. Sayidiman Magetan, Jawa Timur dan telah mendapat persetujuan etik dari Komite Etik Penelitian Kesehatan Universitas Surabaya (No:025-OL/KE/IX/2020). Proses pengambilan data dilakukan dengan menggunakan data sekunder pada rekam medis pasien.

Responden pada penelitian ini adalah ibu hamil yang melahirkan di RSUD Dr. Sayidiman Magetan periode Januari 2018 -
Desember 2019. Semua data responden yang memenuhi kriteria inklusi (memiliki catatan rekam medis, skor APGAR dan status kesehatan ibu) pada periode tersebut akan digunakan sebagai sampel penelitian. Data responden yang dibutuhkan adalah riwayat preeklamsia ibu hamil pada status kesehatan ibu dan riwayat afiksia neonatorum pada rekam medis yang dinilai melalui skor APGAR. Data yang sudah diperoleh akan dianalisis untuk mengetahui faktor resiko (Prevalence Risk) dan hubungan (Uji Spearman) antar kedua variabel.

\section{HASIL}

Distribusi karakteristik dari responden penelitian meliputi usia dan status gestasi ibu. Karakteristik responden dijabarkan pada Tabel 1.

Tabel 1. Distribusi Karakteristik Sampel

\begin{tabular}{|c|c|c|c|c|c|c|}
\hline \multirow[b]{2}{*}{ No } & \multirow[b]{2}{*}{ Kelompok } & \multirow[b]{2}{*}{ Klasifikasi } & \multicolumn{2}{|c|}{ Preeklamsia } & \multicolumn{2}{|c|}{ Non-Preeklamsia } \\
\hline & & & Frekuensi & $\begin{array}{c}\text { Persentase } \\
(\%)\end{array}$ & Frekuensi & $\begin{array}{c}\text { Persentase } \\
(\%) \\
\end{array}$ \\
\hline \multirow{3}{*}{1} & \multirow{3}{*}{ Usia } & $18-25$ tahun & 86 & 40,0 & 30 & 27,0 \\
\hline & & $26-35$ tahun & 40 & 18,6 & 48 & 43,2 \\
\hline & & $36-45$ tahun & 89 & 41,4 & 33 & 29,8 \\
\hline \multirow{5}{*}{2} & \multirow{5}{*}{ Paritas } & Nulipara & 5 & 2,3 & 1 & 0,9 \\
\hline & & Primipara & 37 & 17,2 & 15 & 13,5 \\
\hline & & Multipara & 42 & 19,5 & 20 & 18,0 \\
\hline & & Grand Multigravida & 49 & 22,8 & 21 & 19,0 \\
\hline & & Primigravida & 82 & 38,2 & 54 & 48,6 \\
\hline
\end{tabular}

Berdasarkan Tabel 1. Ibu preeklamsi dengan rentang usia 18-25 tahun sejumlah 86 orang $(40 \%)$, rentang usia $26-35$ tahun sejumlah 40 orang $(18,6 \%)$, dan rentang usia 36-45 tahun sejumlah 89 orang $(41,4 \%)$. Ibu bayi non-preeklamsi memiliki rentang usia 18-25 tahun sejumlah 30 orang $(41,4 \%)$, rentang usia $26-35$ tahun sejumlah 
ISSN 1978-2071 (Print); ISSN 2580-5967 (Online) Jurnal IImiah Kedokteran Wijaya Kusuma 10(1): 11-19, Maret 2021

48 orang $(43,2 \%)$ dan rentang usia $36-45$ tahun sejumlah 33 orang $(29,8 \%)$.

Paritas ibu hamil dengan preeklamsia memperlihatkan Nulipara (Belum pernah melahirkan bayi hidup) sejumlah 5 orang (2,3\%), Primipara (Pernah melahirkan bayi hidup untuk pertama kali) sejumlah 37 orang $(17,2 \%)$, Multipara (lebih dari 2 kali melahirkan) sejumlah 42 orang $(19,5 \%)$, grand multigravida (lebih dari 6 kali melahirkan) sejumlah 49 orang $(22,8 \%)$, Primigravida (kehamilan pertama kali) sejumlah 82 orang $(38,1 \%)$. Sedangkan, ibu preeklamsi non-preeklamsia memperlihatkan Nulipara (Belum pernah melahirkan bayi hidup) sejumlah 1 orang $(0,9 \%)$, Primipara (Pernah melahirkan bayi hidup untuk pertama kali) sejumlah 15 orang (13,5\%), Multipara (lebih dari 2 kali melahirkan) sejumlah 20 orang (18\%), grand multigravida (lebih dari 6 kali melahirkan) sejumlah 21 orang (19\%), Primigravida (kehamilan pertama kali) sejumlah 54 orang $(48,6 \%)$.

Tabel 2. Hasil Uji Chi-square antar kedua kelompok

\begin{tabular}{|c|c|c|c|c|c|}
\hline & \multicolumn{2}{|c|}{ Asfiksia } & \multicolumn{2}{|c|}{ Non-Afiksia } & \multirow[t]{2}{*}{ P-value } \\
\hline & Frekuensi & Persentase (\%) & Frekuensi & Persentase (\%) & \\
\hline Preeklamsia & 157 & 75,1 & 58 & 49,6 & \\
\hline Non-Preeklamsia & 52 & 24,9 & 59 & 50,4 & 0,000 \\
\hline Total & 209 & 100 & 117 & 100 & \\
\hline
\end{tabular}

Berdasarkan Tabel 2, didapatkan bahwa ibu preeklamsi yang melahirkan bayi dengan kondisi asfiksia sebanyak 157 orang dan non asfiksia sebanyak 58 orang. Sedangkan, ibu yang tidak mengalami preeklamsi melahirkan bayi dengan kondisi asfiksia sebanyak 52 orang dan non asfiksia sebanyak 59 orang $(50,4 \%)$. Selanjutnya, dilakukan uji Chi-square untuk melihat perbedaan antara kedua kelompok dan didapatkan nilai p-value sebesar 0,000 $(p<0,05)$ yang menunjukkan adanya perbedaan yang signifikan.

Tabel 3. Hasil uji faktor resiko antar kedua kelompok

\begin{tabular}{cccccc}
\hline \multirow{2}{*}{ Faktor Risiko } & \multicolumn{3}{c}{ Efek } & P-value & \multirow{2}{*}{$\begin{array}{c}\text { Odd } \\
\text { Ratio }\end{array}$} \\
\cline { 2 - 3 } & Asfiksia & Non-Afiksia & & \multirow{2}{*}{0,000} & 3,071 \\
\hline Preeklamsia & 157 & 58 & 59 & \\
\hline
\end{tabular}

Berdasarkan Tabel 3. didapatkan hasil uji faktor risiko dengan menggunakan odd ratio dan didapatkan nilai Odd Ratio sebesar 3,071. Hal ini dapat dinyatakan bahwa ibu hamil yang memiliki preeklamsia 3,071 lebih beresiko melahirkan bayi dengan afiksia dibanding dengan ibu hamil tanpa preeklamsia. 
Studi Faktor Risiko Preeklamsi terhadap Kejadian Asfiksia Neonatorum di RSUD dr. Sayidiman... Vivian Ade Wilsye Maria Mongdong, Rivan Virlando Suryadinata, Sawitri Boengas, Siti Ariffatus Saroh

\section{PEMBAHASAN}

Hasil penelitian memperlihatkan bahwa faktor usia dan jumlah kehamilan juga memberikan pengaruh terhadap kejadian preeklamsia (Tyas et al, 2019). Pada distribusi karakteristik dari penelitian ini, ibu yang hamil dengan rentang usia 3645 tahun lebih berisiko mengalami preeklamsi dibandingkan dengan ibu yang hamil pada rentang usia lainnya. Hal ini dikarenakan alat reproduksi wanita pada usia 20-35 tahun telah berkembang dengan baik dan berfungsi secara maksimal, sehingga risiko terjadinya preeklamsia menjadi lebih kecil dibandingkan dengan usia yang lebih tua. Selain itu, risiko preeklamsia dan komplikasi lainnya lebih sering terjadi pada usia $<20$ tahun atau $>35$ tahun (Evi, 2017; Gunawan, 2010).

Jumlah paritas pada seorang ibu juga mempengaruhi terjadinya preeklamsia. Primigravida lebih berisiko mengalami preeklamsi dikarenakan baru pertama terbentuk vilus korion, sehingga terjadi mekanisme imunologi yang dilakukan oleh HLA-G (human leukocyte antigen G) terhadap antigen plasenta belum terbentuk secara sempurna sehingga proses implantasi trofoblas ke jaringan desidual ibu menjadi terganggu (Novianti, 2016). Selain primigravida, grand multigravida dan mutipara juga memiliki risiko yang tinggi untuk terjadinya preeklamsi. Wanita yang pernah melahirkan lebih dari 3 kali terjadi penurunan fungsi pada sistem reproduksi dikarenakan terlalu sering organ rahim mengalami peregangan pada saat kehamilan berlangsung (Suwanti dan Safitri, 2014).

Pada penelitian memperlihatkan peningkatan kejadian afiksian neonatorum pada ibu hamil dengan riwayat preeklamsia lebih besar dibandingkan dengan ibu hamil non-preeklamsia. Hal ini dikarenakan pada preeklamsi terjadi vasokonstriksi yang meluas akibat hipertensi yang diderita ibu selama kehamilan. Vasokonstriksi tersebut dapat menyebabkan penurunan suplai darah ke plasenta, sehingga terjadi penurunan oksigen pada janin. Gangguan pertukaran gas antara oksigen dan karbon dioksida mengakibatkan terjadi hipoksia janin yang mempengaruhi proses adaptasi bayi saat persalinan yaitu adaptasi pernapasan akibat aktivitas bernapas dan menangis. Hal tersebut memberikan dampak kesehatan jangka panjang yaitu gangguan sistem organ vital seperti jantung, paru-paru, ginjal, dan otak serta dapat menyebabkan kematian pada bayi (Setiyaningrum, 2017). Namun pada Ibu non preeklamsi juga memiliki risiko melahirkan bayi dengan kondisi asfiksia walaupun dengan risiko yang lebih kecil. Berbagai faktor dapat memicu terjadinya afiksia pada 
neonatorum seperti akibat obat-obatan yang dapat menekan spontanitas napas yang dikonsumsi selama kehamilan, hipoksia intrauterine, bayi prematur, penyakit atau cacat bawaan bayi, persalinan dengan tindakan (sungsang, bayi kembar, distorsia bahu, ekstrasi vakum, ekstrasi forsep), air ketuban bercampur meconium (Mochtar, 1998).

Berbagai macam dampak negatif dari kesehatan akan banyak dijumpai pada ibu hamil dengan riwayat preeklamsia. Peningkatan angka kejadian afiksia neonatorum pada preeklamsia di RSUD dr. Sayidiman Magetan pada tahun 2018 dapat memberikan gambaran risiko morbiditas dan mortalitas pada ibu maupun bayi dengan riwayat preeklamsi. Berbagai program pencegahan sangat dibutuhkan untuk dapat menekan risiko tersebut baik sebelum dan sesudah kehamilan. Selain itu, peranan pemerintah dan masyarakat secara aktif juga berperan penting dalam pencegahan ibu hamil preeklamsi.

\section{KESIMPULAN}

Ibu hamil dengan preeklamsia memiliki hubungan yang kuat terhadap peningkatan kejadian afiksia neonatorum hingga mencapai tiga kali lipat dibandingkan dengan ibu hamil tanpa preeklamsia di RSUD dr. Sayidiman Magetan pada tahun 2018

\section{DAFTAR PUSTAKA}

Burton G, Yung HW, Cindrova-Davies T, Charnock-Jones DS, 2009. Placental Endoplasmic Reticulum Stress and Oxidative Stress in The Pathophysiology of Unexplained Intrauterine Growth Restriction and Early Onset Preeclampsia. Placenta. 30:43-48 Carty DM, Delles C, Dominiczak AF, 2010. Preeclampsia and Future Maternal Health. J Hypertens. 28:13491355

Cunningham FG, Leveno KJ, Bloom SL, et al, 2018. Williams Obstetrics. $25^{\text {th }}$ edition.

De Giacomi F, Vassallo R, Yi ES, Ryu JH, 2018. Acute Eosinophilic Pneumonia. Causes, Diagnosis, and Management. Am J Respir Crit Care Med. 197:728-36.

El-Sayed AAF, 2017. Preeclampsia: A Review of The Pathogenesis and Possible Management Strategies Based on Its Pathophysiological Derangements. Taiwan J Obstet Gynecol. 56: 593-8.

Evi H, 2017. Hubungan Usia dengan Kejadian Preeklampsia Pada Ibu Bersalin Di RSUD Muntilan. DIY Yogyakarta.

Fisher SJ, 2015. Why is Placentation Abnormal

\section{in}


Studi Faktor Risiko Preeklamsi terhadap Kejadian Asfiksia Neonatorum di RSUD dr. Sayidiman... Vivian Ade Wilsye Maria Mongdong, Rivan Virlando Suryadinata, Sawitri Boengas, Siti Ariffatus Saroh

Preeclampsia?. American Journal

of Obstetrics \&

Gynecology. 213(suppl 4): S115S122.

Grum T, Hintsa S, Hagos G, 2018. Dietary

Factors Associated with

Preeclampsia or Eclampsia Among

Women in Delivery Care Services

in Addis Ababa, Ethiopia: A Case

Control Study. BMC Res Notes. 11:

683.

Gunawan S, 2010. Reproduksi Kehamilan dan Persalinan. CV Graha, Jakarta.

Mayrink J, Costa ML, Cecatti JG, 2018. Preeclampsia in 2018: Revisiting Concepts, Physiopathology, and Prediction. Scientific World Journal. 2018: 6268276.

Mochtar R, 1998. Sinopsis Obstetri Edisi 2, Jilid 1. Buku Kedokteran EGC, Jakarta.

Novianti H, 2016. Pengaruh Usia dan Paritas terhadap Kejadian Pre Eklampsia di RSUD Sidoarjo. Jurnal IImiah Kesehatan. 9(1): 25-31.

Purswani JM, Gala P, Dwarkanath P, Larkin HM, Kurpad A, Mehta S, 2017. The Role of Vitamin D in Preeclampsia: A Systematic Review. BMC Pregnancy Childbirth. 2017 (17): 231.

Redman C, Staff A, 2015. Preeclampsia, Biomarkers, Syncytiotrophoblast

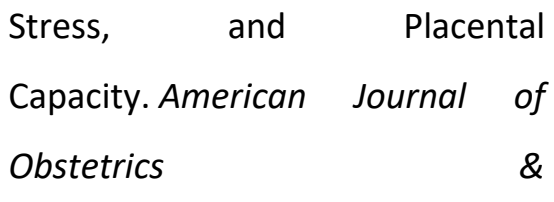

Gynecology. 213(suppl 4): S9.e1S9-11.

Setiyaningrum S, 2017. Buku Ajar Kegawatdaruratan Maternitas pada Ibu Hamil, Bersalin, Nifas. Indomedia Pustaka, Yogyakarta.

Spracklen CN, Ryckman KK, Triche EW, Sattlas A, 2016. Physical Activity During Pregnancy and Subsequent Risk of Preeclampsia and Gestational Hypertension: A Case Control Study. Matern Child Health J. 20(6): 1193-1202.

Suryadinata RV, Wirjatmadi B, 2020a. Selenium Linked to Increased Antioxidant Levels and Decreased Free Radicals in Lung Tissue of Wistar Rats Exposed to E-Cigarette Smoke. Journal of Global Pharma Technology. 12(9): 32-39.

Suryadinata RV, Wirjatmadi B, Adriani M, Lorensia A, 2020b. Effect of Age and Weight on Physical Activity. Journal of Public Health. 9(1840): 187-190.

Suryadinata RV, Wirjatmadi B, Adriani M, Sumarmi S, 2018. Effects of Knowledge of Vitamin $D$ on Attitudes toward Sun Exposure among Middle-Aged and Elderly 
ISSN 1978-2071 (Print); ISSN 2580-5967 (Online) Jurnal IImiah Kedokteran Wijaya Kusuma 10(1): 11-19, Maret 2021

Indonesian Adults. Indian Journal

of Public Health Research \& Development. 9: 11-15.

Suwanti EPW dan Safitri NA, 2014.

Hubungan Tekanan Darah Dan

Paritas Dengan Kejadian

Preklampsia Di Ruang Bersalin

RSUP NTB Tahun 2012. Media Bina

Ilmiah. 8(1): 25-30.

Timur DK, 2017. Profil Kesehatan Provisi Jawa Tmur. Surabaya:

Kementerian Kesehata Republik Indonesia.

Tranquilli AL, Dekker G, Magee L, Roberts J, Sibai BM, Steyn W, 2014. The Classification, Diagnosis and Management of The Hypertensive Disorders of Pregnancy: A Revised Statement from the
ISSHP. Pregnancy Hypertens. 4:97104.

Tyas BD, Lestari P, Akbar MI, 2019. Maternal Perinatal Outcomes Related to Advanced Maternal Age in Preeclampsia Pregnant Women. J Family Reprod Health. 13: 191200.

Uzan J, Carbonnel M, Piconne O, Asmar R, Ayoubi J, 2011. Preeclampsia: Pathophysiology, Diagnosis, and Management. Vasc Health Risk Manag. 7: 467-474.

WHO, 2013. WHO Guidline for Measuring Maternal Mortality from a Census. World Health Organization.

WHO, 2016. Monitoring Health for The SGDs. France: World Health Organization. 